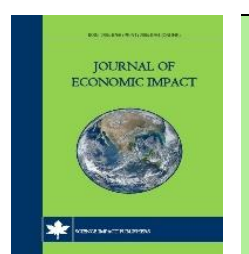

Available Online

Journal of Economic Impact

ISSN: 2664-9764 (Online), 2664-9756 (Print)

http://www.scienceimpactpub.com/jei

\title{
INVESTIGATING RELATIONSHIP OF FOOD SECURITY WITH MARKET APPROACHABILITY WITH RESPECT TO HOUSEHOLD FOOD INSECURITY ACCESS INDEX
}

\author{
Mahwish Munawar a, Xu Shiwei a, Yu Wen a, Muhammad Luqman b,* \\ ${ }^{a}$ Agricultural Information Institute, Chinese Academy of Agricultural Sciences, Beijing, China \\ ${ }^{b}$ Department of Agricultural Extension, College of Agriculture, University of Sargodha, Sargodha, Pakistan
}

\section{ARTICLE INFO}

\section{Article history}

Received: August 12, 2021

Revised: November13, 2021

Accepted: November 18, 2021

\section{Keywords}

Farming households

HFIAS

Food security

Punjab

Pakistan

\section{ABSTRACT}

Globally rural households with less landholding, especially from developing countries, are more food insecure due to a lack of resources accessibility and fewer marketplaces. This study was planned to inspect the relationship between household food security and market approachability concerning Household Food Insecurity Access Index (HFIAS). For data collection, 200 farming households from five districts (Faisalabad, Sheikhupura, Rawalpindi, Rahim Yar Khan and Mianwali) from five agro-ecological zones of Punjab were selected as respondents. So, the results can be comprehensive and widespread at the provincial level. Interviews with household heads were conducted with the help of a wellstructured and pre-tested interview questionnaire. Food security was calculated with the help of the household food insecurity access score, which calculates food intake for one month and indicates the level of food security based on food consumption during the last thirty days. According to research findings of 46 percent are severely food insecure, and the main reason behind so much food insecurity is rising food prices, increasing fuel prices, transportation costs, lack of agricultural input, and very few marketplaces. Binary logistic regression shows that landholding, earning hands in family, and the distance of farm from the market have a significant effect on the food security status of the family. As the distance of farm from market place increases labour costs, transportation costs, and fuel charges that affect household livelihood inversely. The results suggest that local food security can be enhanced by creating off-farm employment opportunities, improved transportation facilities, and road infrastructure.

\footnotetext{
*Email: muhammad.luqman@uos.edu.pk

https://doi.org/10.52223/jei3032101

(C) The Author(s) 2021.

This is an open access article under the CC BY license (http://creativecommons.org/licenses/by/4.0/).
}

\section{INTRODUCTION}

Every one out of four persons is moderately or severely food secure. A total number of food insure population is around 2 billion which is quite alarming (Omotesho et al., 2016) as well as up to 663 million and 697 million population are vulnerable to food insecurity and severely food insecure respectively. The majority of undernourished, food insecure people belong from developing and under developed countries (Von Grebmer et al., 2014). Regardless of this, the agriculture sector is producing much more than ever before. Around the globe, countries either developed or developing show the slenderest interest in investing in the agriculture sector, which is the main reason that farming communities throughout the world are more prone and vulnerable to poverty and food insecurity (Waha et al., 2018). During the last few decades, an abrupt decline in agricultural research and development was noticed (Seng, 2016). Most of the countries prefer to invest in cash crops that can be exported and ad on country revenue from foreign exchange (McIntyre, 2009). The main proportion of the population of developing countries lives in rural areas, mainly depends upon the agriculture sector for their livelihoods (Rudenko et al., 2013) but due to lack of job opportunities and fewer market places greatly affects household food security (De Fazio, 2016).

Food security is a dense and versatile conception that correlates three intricate phenomena, i.e., food availability, food accessibility, and food utilization (Feliciano, 2019; McIntyre, 2009). Food insecurity is not due to lack of availability or less knowledge about requirements and proper utilization of nutrients but also due to lack of affordability due to less supply and high food prices (Von Grebmer et al., 2011). Less crop production due to climate change, resource and water scarcities, abrupt change in temperature and annual rainfall, and floods has increased pressure on the food supply chain of many countries (Diamond et al., 2014).

Developing world, especially South Asian countries like India, Pakistan, and Bangladesh, are extremely affected by 
environmental disasters like floods, earth quake, drought, and so on, which cause financial instability. Although Pakistan is an agricultural country, the majority of farmers own less than 2 hectares with little or no access to agriculture extension services and resources. Due unavailability of agricultural facilities and no assistance from governmental institutes, farmers have to opt for other routes of livelihood to fulfill their needs (Hayat et al., 2016; Nkala, 2011).

Betterment in the food security situation is not much visible at the grassroots level due to multiple factors like complex and high-risk food supply systems (Gebresenbet \& Boso, 2012; Simons et al., 2005). Insecure marketing system, high wage rates, high transportation costs are some of the major reasons that directly or indirectly affect the situation of food security in developing countries (Løvendal et al., 2004). The situation of food insecurity can be overcome by improving accessibility by up-gradation of marketing system (Munawar et al., 2021). Accessibility can be explained as the disposal of food without any inconvenience and hassle. Food demand and distribution system depend upon two factors one is food and the other is a marketing system. Marketing systems can be improved by defining the roles of different stakeholders (Bhutto \& Bazmi, 2007). Market accessibility is the most important factor that affects household food security due to multiple stakeholders that are closely interlinked with each other like the producer, processor, middle man, trader, and retailer and all these stakeholders affect the food supply chain system significantly (Ahmed et al., 2016).

Market access has more impact on rural households' food security because farmers are manufacturers and ' users at the same time. So, market access has a two-way relationship with rural families. Farmers use markets place to sell their products, as well as to buy food and other fewer cities of life to sustain their basic requirements (Ahmed et al., 2015). Multiple factors hinder farming communities from easy access to the market that is long distance, lack of information regarding marketing system, high transportation cost and so on (Abid et al., 2015). So, few transportation costs, better setup, easy and cost-effective access to the market, and controlled food prices have a significant effect in improving the food security situation at the grassroots level; hence, better infrastructure and easy market access can play an important role in sustaining local food security (Akaakohol \& Aye, 2014).

Market access can be elaborated on different parameters like distance, transportation cost, traveling time, condition of roads. As well as market access is also associated with other institutional factors like availability of extension service, the influence of middlemen in the marketing system, choice of market, and some socio-economic factors like age and gender of household head, landholding, earning hands in family and total income (Ishaq et al., 2018). All these factors along with market access greatly affect household food security. To date, we can find literature on food insecurity but unable to find much literature on the relationship and effect of the market on food security. Keeping in view this study gap, this study is planned to study the relationship of food security with market approachability concerning household food insecurity access index.

\section{METHODOLOGY}

\section{Data Collection Procedure}

This study used both primary and secondary data. Secondary data sources included the libraries of the University of Agriculture Faisalabad and the Chinese Academy of Agriculture Sciences, NGOs offices, academic and research institutes, journals, publications, and online sources. We consulted publicly accessible publications and data on several family food security programs operated by international organizations (FAO, IFPRI, and WFO). Primary data were gathered in the field via interviews with agricultural family leaders. The data gathering instrument was a pre-designed and pre-tested questionnaire. Interviews with household heads and focus groups with the whole family were done in order to get a better understanding of the home's food consumption system. We collected data on several food security metrics, yearly consumption, and prices of various food categories.

\section{Sample Size}

A multistage sample technique was used to identify 200 farming families from five agro-climatic zones. Punjab province was chosen in the first step because it is separated into five distinct agro-climatic zones (Ahmed et al., 2016; Akram \& Sial, 2019). According to the Pakistan Bureau of Statistics, Punjab province is divided into 36 districts, five of which were determined using a stratified purposive sample approach (Faisalabad, Sheikhupura, Rawalpindi, Rahim Yar Khan, and Mianwali). Each zone was assigned one community based on the selection criteria. The region was chosen to ensure that the yields of five important crops (wheat, rice, sugarcane, cotton, and maize) were uniform. The final step included the random selection of one hamlet from each district. We randomly picked 40 homes from each neighbourhood in the fourth step. This criteria was used to select the 200 families for the sample.

\section{Empirical Model}

Binary logistic regression is an extension of simple linear regression. Logistics regression is a statistical method used to estimate the relationship between the dependent and independent variables (Hahn \& Soyer, 2005). Especially when the predicted variable is binary or dichotomous in nature, (e.g., Gender [male /female], Education [yes/ no], Income [high/ low], etc.).

The general logistic model may be written as; logit $\left(\delta_{i}\right)=\alpha+\beta_{1} X_{1}+\beta_{2} X_{2}+\beta_{3} X_{3}+\beta_{4} X_{4}+$ $\beta_{5} X_{5+\cdots+} \beta_{k} X_{k}+\varepsilon_{i}$ $\alpha$ is interception term $\beta$ is regression coefficient

$\mathrm{X}_{\mathrm{i}}$ is different variables use in model $\varepsilon_{\mathrm{i}}$ is error term in model

The binary logistic regression model was used as we coded the dependent variables as 0 and 1 and claimed that this set of variables foretell the probability that "Y" $=1$. The regression equation was transformed to make a formula so that we can calculate $\mathrm{Y}=1$. 
$p(Y=1)=\frac{1}{1}+\exp \left[-a\left(\alpha+\beta_{1} x_{1}+\beta_{2} x_{2}+\beta_{3} x_{3}+\cdots \beta_{k} x_{k}\right)\right]$

Above mention, the function is known as logistic distribution function, and it can be estimated by ML (maximum likelihood technique); the most important characteristic of this function is that it ensures that the probability ranges from 0 to 1 . As we know, regression calculations estimate positive to negative infinity values (Chen \& Tsurumi, 2010). It is called log-odds and can be written as;

$$
\begin{aligned}
& \operatorname{Logit}[p(Y=1)]=\alpha+\beta_{1} x_{1}+\beta_{2} x_{2}+\beta_{3} x_{3}+\cdots \beta_{k} x_{k} \\
& \text { Logit }[p(Y=1)]=\operatorname{loge}\left[\frac{p(y-1)}{1}-p(y=1)\right] \\
& \text { Hence; } \\
& \ln \left[\frac{p}{1-p}\right]=\alpha+\sum b_{i} x_{i}
\end{aligned}
$$

So final form of our estimated model is;

$$
\begin{aligned}
& \operatorname{Ln}\left[\frac{p}{1-P}\right]=\beta_{0}+\beta_{1} y_{1}+\beta_{2} y_{2}+\beta_{3} y_{3}+\beta_{4} y_{4}+\beta_{5} y_{5}+\beta_{6} y_{6}+ \\
& \beta_{7} y_{7}+\beta_{8} y_{8}+\beta_{9} y_{9}+\beta_{10} y_{10}+\beta_{11} y_{11}+\epsilon_{i}
\end{aligned}
$$

Table 1. Description of variables used in the model.

\begin{tabular}{ll}
\hline Variables and description & Units of variables \\
\hline Dependent variable & \\
\hline Household Food insecurity Index & $\mathrm{D}=1$ if HH is food secure; $0=$ otherwise \\
\hline Independent variables & \\
\hline$\beta_{1}=$ Age of household head & Age of HH head in a number of years \\
$\beta_{2}=$ Education of household head & $\mathrm{D}=1$ if HH head is literate; $0=$ otherwise \\
$\beta_{3}=$ Household size & Number of household members \\
$\beta_{4}=$ Earnings hands in family & Number of independent family members \\
$\beta_{5}=$ Total Income & In Rupees \\
$\beta_{6}=$ Landholding & Area farmer own \\
$\beta_{7}=$ Transportation cost & In Rupees \\
$\beta_{8}=$ Distance to road & Number of kilometers by which the villages is away from the market \\
$\beta_{9}=$ Distance to market & Number of kilometers by which the villages is away from the market \\
$\beta_{10}=$ Marketing facility & $D=1$ if HH have facility $; 0=$ otherwise \\
$\beta_{11}=$ role of middlemen & D = 1if there is any role of middle man 0 otherwise \\
\hline
\end{tabular}

To study the effect of market approachability on household food security to the majority HFIAS, binary logistic regression model was used. Table 1 shows the variables used in this study.

\section{Household Food Insecurity Access Score (HFIAS)}

HFIAS is used to measure household food security based on food consumption patterns during the last thirty days. There are three levels of food insecurity; anxiety, inadequate quantity, and quality (Coates et al., 2007; Vaitla et al., 2015). This index measures food security based on quality and quantity without considering the nutritional value of food (Coates et al., 2007; Mango et al., 2018; Vaitla et al., 2015). This index highlights consumption-related plans, the psychological and behavioral effect of food insecurity on household members. All the above-mentioned three factors of household food security were calculated with the help of nine questions that mainly focus on the level of food insecurity and the occurrence of events. All these occurrences address the increasing level of food insecurity.

The occurrence questions can be brief as follows:

eating less preferred foods; upset about food; the limited variety of variety; eating less favorite foods; having smaller quantities than needed for growth and development; less frequent meals; going to bed hungry; no food for the whole day; many days without food. All these questions were asked regarding occurrence during the last one month and then respondents were asked about the severity of occurrence. If the respondent experiences any of the above situations, he will respond in yes that will be 1 . If the respondent responded positively, then he has to respond to questions related to the previous question; each question is followed by a series of questions that address the severity of food insecurity $11=$ rarely, 2 = sometimes, and $3=$ often). A minimum score of HFIAS is zero when the household head responded negatively to all questions, and 27 will be maximum when all the questions are answered positively and the household experiencing acute food insecurity.

HFIAS $(0-27)=\mathrm{Q} 1 \mathrm{a} * \mathrm{~F} 1+\mathrm{Q} 2 \mathrm{a} * \mathrm{~F} 2+\mathrm{Q} 3 \mathrm{a} * \mathrm{~F} 3+\mathrm{Q} 4 \mathrm{a} * \mathrm{~F} 4+$ $\mathrm{Q} 5 \mathrm{a} * \mathrm{~F} 5+\mathrm{Q} 6 \mathrm{a} * \mathrm{~F} 6+\mathrm{Q} 7 \mathrm{a} * \mathrm{~F} 7+\mathrm{Q} 8 \mathrm{a} * \mathrm{~F} 8+\mathrm{Q} 9 \mathrm{a} * \mathrm{~F} 9$

\section{RESULTS AND DISCUSSION}

The main objective of this study was to determine the relationship of market accessibility on the food security of rural households during the last 30 days. Descriptive analysis was carried out of the social characteristics of our respondents in every household of our data. Table 2 depicts the results of the descriptive study of demographic attributes. The majority of household heads belong from the age group of 58 years as well as the average number of household members is 5 , and about 3 to 4 members of every household participate in the income of the family (Mahmood et al., 2014).

The majority of farming households own less than 2 hectares of land as well as the majority of them own livestock that contribute a lot to their income (Munawar et al., 2013). Moreover, the average income of the farming household is 305 US\$ per month which is far less than the standard income of any household to fulfill basic needs (Sati \& Vangchhia, 2017). The average distance of the farm from the main road is $10 \mathrm{~km}$ and the average distance of the farm from the market is $76 \mathrm{~km}$. However, a single household spends 1958 Pakistani rupees in terms of transportation cost (Yousaf et al., 2018). As well as out of 200 household's only 73 households are food secure. 
Table 2. Descriptive analysis of variables.

\begin{tabular}{llllll}
\hline Variables & Obs. & Mean & Std. Dev & Min & Max \\
\hline Age & 200 & 58 & 13.77019 & 24 & 94 \\
Education & 200 & 0.785 & 0.4118533 & 0 & 1 \\
Household Size & 200 & 5.595 & 2.11027 & 2 & 12 \\
Earning hands in the family & 200 & 2.66 & 1.508568 & 1 & 8 \\
Income source & 200 & 2.6 & 0.7957172 & 1 & 3 \\
Landholding & 200 & 4.82 & 5.302659 & 1 & 40 \\
Total income & 200 & 611135 & 431012.8 & 25000 & 2460000 \\
\hline
\end{tabular}

Table 3. Household food insecurity access score.

\begin{tabular}{|c|c|c|c|}
\hline Variable & $\begin{array}{l}\text { Severe } \\
\text { food insecure household }\end{array}$ & $\begin{array}{l}\text { Borderline } \\
\text { food consumption }\end{array}$ & Food Secure \\
\hline HFIAS & $46 \%$ & $31 \%$ & $23 \%$ \\
\hline
\end{tabular}

According to Table 3, the majority of households experienced severe food insecurity during the last thirty days and only 23 $\%$ of households are food secure and eat their desired food during the past one month (Gulab et al., 2018). It is quite alarming that rural households that have a dual relationship with the food demand system experience food insecurity.

\section{Effect of Socio-economic Characteristics on Household Food security}

According to Binary logistic regression, some variables have a significant influence on rural household food security, according to Table 4. Education and Age of household heads affect household food security in significant ways, but the odds Ratio of Age shows that as the average age of household heads increases, the level of food security of households also increases. Household size has a significant and inverse relationship with household food security if one member increase in the family household will have to face food insecurity. Due to the increase in a family member earning, the burden and budget of the family divide into more people without any increase in household income (Harris-Fry et al., 2015; Gulab et al., 2018). Increase in family members drag the household toward poverty and food insecurity.

Table 4. Results of Binary Logistic Regression.

\begin{tabular}{lllll}
\hline Food Security & Odds Ratio & Std. Err. & P>z & Conf. \\
\hline Age & 1.003346 & .0502083 & 0.947 & .9096113 \\
Education & 0.7332973 & .8021044 & 0.777 & .0859426 \\
Household size & 0.6675059 & .1606254 & $0.093^{* * *}$ & .4165106 \\
Earning hands in the family & 1.000003 & $1.84 \mathrm{e}-06$ & 0.147 & .9999991 \\
Landholding & 1.014974 & .0852203 & $0.009^{*}$ & .8609655 \\
Total income & 0.2837378 & .1720054 & $0.038^{* *}$ & .0864786 \\
Transportation cost & 0.9996437 & .0003439 & $0.013^{* *}$ & .9989698 \\
Availability of marketing facility & 1.950434 & 1.909509 & 0.495 & .2862794 \\
Role of middleman & 3.94668 & 4.831368 & $0.002^{*}$ & .358282 \\
Distance of farm to the road & 1.422639 & .3638452 & 0.168 & .8617808 \\
Distance from market to farm & 0.775784 & .0575741 & $0.001^{*}$ & .6707638 \\
_cons & 509.0699 & 1779.904 & $0.005^{* * *}$ & .5378362 \\
\hline
\end{tabular}

Moreover, earning hands in the family also plays a significant role in household food security as the number of earning hands will increase chances of the family to attain food security will also increase to $0.72 \%$ that's quite high chances and supported by other research findings (Khan et al., 2018). As many members of the family earn, the standard of living increases and the issue of food insecurity will be minimum but when there are only a few members of the family who have to feed the whole family, then the level of food security will decrease. As well as the total income of the household has a positive association with the level of food security. As many members of the family start earning, the income of the household will increase, which will increase the income of the family (Hayat et al., 2016).

A highly significant and positive impact of large landholding on the food security of the household is observed. Because the family has more revenue, resources to enjoy prosperity as well as have more chances to be food secure, these results correlate with existing research findings (Harris-Fry et al., 2015; Seng, 2016; Sheikh et al., 2020). In Pakistan, mostly farming 
households own livestock and no doubt livestock has a positive association with the level of food security of the household (Munawar et al., 2013). In rural areas of Pakistan, female members of the household not only make dairy products for the consumption of the family but also sell dairy products that help them to generate revenue (Akram \& Sial, 2019).

Effect of Access to the Market on Household Food Security During research analysis, it was found that Market and marketing facilities play a very important role in determining household food security. As the availability of the market indicates, availability and easy accessibility to food easy and efficient Market access can be evaluated with the help of a few indicators like availability of marketing facility, transportation cost, the role of middlemen, the distance of farm from the main road and market and so on (Hoang, 2018). The first indicator of the availability of a marketing facility has a positive relation with household food security and increases the chance of food security up to $2 \%$ (Gelli et al., 2015). If a family has easy access to the market to sell their products at a good price they will be able to buy stuff of their need especially food items (Ahmed et al., 2017).

Likewise, the Indicator distance of farms from the market is highly significant at $1 \%$ and negatively related to household food security. Large distance to market increase the chances of the household being food insecure (0.67) because the large distance to market ultimately increases transportation cost, time consumed in transportation, high labor rate, as well as long traveling time will reduce the life of the product that causes reduction of the price of the commodity. Fewer profit results in less income of the family which will cause food insecurity (Aku et al., 2018). Many studies in the literature have revealed that high transportation cost severely affect household food security. According to results increase in transportation costs have (50\%) effect on household food security (Aku et al., 2018; Shahbaz et al., 2010; Yousaf et al., 2018). Many other factors like high crop disease, lack of resources, increase in debt, high-interest rates, taxation on transactions, high food prices, and transportation cost directly affect food security as well as poor health conditions, large family size is some of the factors that indirectly affect the household level of food security but cannot be ignored (Drysdale et al., 2021). The majority of respondents responded that fluctuation in the price of agricultural inputs, lack of irrigation water, attack of insects and pests, natural hazards are some of the nightmares for farming communities that greatly affect the financial and food security situation of any farming family. Moreover, many other factors like social system, social conflicts, and gender discrimination are the major factors that can also be the reason behind a household's unstable financial status. Female members of the family are not allowed to interact with an outsider that's the major reason as well as limitation of this study.

\section{CONCLUSIONS AND RECOMMENDATIONS}

The purpose of this study was to investigate the relationship between household food security and market access, and we did so by measuring household food security using the household food insecurity index. A sample of 200 rural households in
Punjab, Pakistan, were chosen for data collection. The effect of market accessibility, distance from the main road, and the abrupt input increase in fuel price are factors that are inversely related to household food security in this study. Climate change and environmental hazards are also significant threats to farmers, and well-designed coping techniques are required to address all of these issues. This implies that a stronger project and focus should be placed on the food delivery outline and foundation. Simple market access and development in the groundwork will not only lower transportation costs but will also increase the accessibility of low-cost food items at the neighborhood level. Furthermore, market access not only improves household livelihoods but also provides them with more employment opportunities to supplement their monthly income.

\section{Acknowledgments}

This study was supported by the National Key R\&D Program of China (Number: 2017YFE0104600) and the CAAS Science and Technology Innovation Project (number; CAAS-ASTIP2020), instituted by the Key Laboratory of Digital Agricultural Early-Warning Technology, Ministry of Agriculture, Beijing, China.

\section{REFERENCES}

Abid, M., Scheffran, J., Schneider, U.A., Ashfaq, M., 2015. Farmers' perceptions of and adaptation strategies to climate change and their determinants: The case of Punjab province, Pakistan. Earth Syst. Dyn. 6, 225243.

Ahmed, U.I., Ying, L., Bashir, M.K., 2015. Food insecurity and copping strategies of micro growers in Punjab, Pakistan. J. Environ. Agric. Sci. 3, 31-34.

Ahmed, U.I., Ying, L., Bashir, M.K., Abid, M., Elahi, E., Iqbal, M.A., 2016. Access to output market by small farmers: The case of Punjab, Pakistan. J. Anim. Plant Sci. 26, 787793.

Ahmed, U.I., Ying, L., Bashir, M.K., Abid, M., Zulfiqar, F., 2017. Diabetes diet, eating and physical activity. PLoS 12(10), 1-15.

Akaakohol, M.A., Aye, G.C., 2014. Diversification and farm household welfare in Makurdi, Benue State, Nigeria. Dev. Stud. Res. An Open Access J. 1, 168-175.

Akram, W., Sial, M., 2019. Food security paper. Sarhad J. Agri. 35, 87-101.

Aku, A., Mshenga, P., Afari-Sefa, V., Ochieng, J., 2018. Effect of market access provided by farmer organizations on smallholder vegetable farmer's income in Tanzania. Cogent Food Agric. 4, 1560596.

Bhutto, A.W., Bazmi, A.A., 2007. Sustainable agriculture and eradication of rural poverty in Pakistan, in: Natural Resources Forum. Wiley Online Library, pp. 253-262.

Chen, G., Tsurumi, H., 2010. Probit and logit model selection. Commun. Stat. Methods 40, 159-175.

Coates, J., Swindale, A., Bilinsky, P., 2007. Household food insecurity access scale (HFIAS) for measurement of food access: indicator guide: version 3. Washington, DC: food and nutrition technical assistance project, academy for educational development. pp. 1-36. 
De Fazio, M., 2016. Agriculture and sustainability of the welfare: the role of the short supply chain. Agric. Agric. Sci. procedia 8, 461-466.

Diamond, A., Tropp, D., Barham, J., Frain, M., Kiraly, S., Cantrell, P., 2014. Food Value Chains: Creating Shared Value To Enhance Marketing Success (No. 176263). United States Department of Agriculture, Agricultural Marketing Service, Transportation and Marketing Program.

Drysdale, R.E., Bob, U., Moshabela, M., 2021. Socio-economic determinants of increasing household food insecurity during and after a drought in the district of ilembe, South Africa. Ecol. Food Nutr. 60, 25-43.

Feliciano, D., 2019. A review on the contribution of crop diversification to Sustainable Development Goal 1 "No poverty" in different world regions. Sustain. Dev. 27, 795-808.

Gebresenbet, G., Bosona, T., 2012. Logistics and supply chains in agriculture and food. In Pathways to Supply Chain Excellence, InTech: London, UK, 2012.

Gelli, A., Hawkes, C., Donovan, J., Harris, J., Allen, S.L., de Brauw, A., Henson, S., Johnson, N.L., Garrett, J. and Ryckembusch, D., 2015. Value chains and nutrition: A framework to support the identification, design, and evaluation of interventions (No. 1413). International Food Policy Research Institute (IFPRI).

Gulab, S., Fazli, R., Umar, H., 2018. Food insecurity and its determinants in rural Khyber Pakhtunkhwa, Pakistan. Asian J. Agric. Biol. 6, 308-315.

Hahn, E.D., Soyer, R., 2005. Probit and logit models: Differences in the multivariate realm. J. R. Stat. Soc. Ser. B 1-12.

Harris-Fry, H., Azad, K., Kuddus, A., Shaha, S., Nahar, B., Hossen, M., Younes, L., Costello, A., Fottrell, E., 2015. Socioeconomic determinants of household food security and women's dietary diversity in rural Bangladesh: a crosssectional study. J. Heal. Popul. Nutr. 33, 1-12.

Hayat, N., Hussain, A., Yousaf, H., 2016. Food demand in Pakistan: Analysis and projections. South Asia Econ. J. 17, 94-113.

Hoang, H.K., 2018. Analysis of food demand in Vietnam and short-term impacts of market shocks on quantity and calorie consumption. Agric. Econ. 49, 83-95.

Ishaq, A., Khalid, M., Ahmad, E., 2018. Food insecurity in Pakistan: A region-wise analysis of trends. Pakistan Insfitute Dev. Econ. Work. Pap. 157.

Khan, Q., Umar Farooq, M., Rizwan Yaseen, M., 2018. Socioeconomic Determinants of Food Security: Evidence from Jhang District of Punjab, Pakistan. Eur. Online J. Nat. Soc. Sci. Proc. 7, 109.

Lovendal, C.R., Knowles, M., Horii, N., 2004. Understanding vulnerability to food insecurity: Lessons from vulnerable livelihood profiling (No. 23794). Food and Agriculture Organization of the United Nations, Agricultural Development Economics Division (ESA).

Mahmood, S., Tabassum, A., Khan, S.A., Jabeen, N., 2014. An investigation of determinants of food security in rural areas of Faisalabad, Pakistan. Mediterr. J. Soc. Sci. 5, 676.

Mango, N., Makate, C., Mapemba, L., Sopo, M., 2018. The role of crop diversification in improving household food security in central Malawi. Agric. Food Secur. 7, 1-10.
McIntyre, B.D., 2009. International assessment of agricultural knowledge, science and technology for development (IAASTD): Synthesis report with executive summary: A synthesis of the global and sub-global IAASTD reports. No. E14-197. 2009.

Munawar, M., Safdar, U., Luqman, M., Butt, T.M., Hassan, M.Z.Y., Khalid, M.F., 2013. Factors inhibiting the participation of rural women in livestock production activities. J. Agric. Res. 51, 213-220.

Munawar, M., Shiwei, X., Wen, Y., Luqman, M., 2021. Resilience to food insecurity among rural households in the Punjab, Pakistan. Sarhad J. Agric. 37, 754-762.

Nkala, P., 2011. Assessing the impacts of conservation agriculture on farmer livelihoods in three selected communities in central Mozambique. Doctoral dissertation, University of Natural Resources and Life Sciences.

Omotesho, O.A., Adewumi, M.O., Muhammad-Lawal, A., Ayinde, O.E., 2016. Determinants of food security among the rural farming households in Kwara State, Nigeria. African J. Gen. Agric. 2, 7-15.

Rudenko, I., Bekchanov, M., Djanibekov, U., Lamers, J.P.A., 2013. The added value of a water footprint approach: Micro-and macroeconomic analysis of cotton production, processing and export in water bound Uzbekistan. Glob. Planet. Change 110, 143-151.

Sati, V.P., Vangchhia, L., 2017. Food Security and poverty, in: A Sustainable Livelihood Approach to Poverty Reduction. Springer, pp. 81-92.

Seng, K., 2016. The effects of market participation on farm households' food security in Cambodia: An endogenous switching approach. (No. 69669). University Library of Munich, Germany.

Shahbaz, B., Ali, T., Khan, I.A., Ahmad, M., 2010. An analysis of the problems faced by farmers in the mountains of Northwest Pakistan: challenges for agri. extension. Pak. J. Agri. Sci 47, 417-420.

Sheikh, S., Iqbal, R., Qureshi, R., Azam, I., Barolia, R., 2020. Adolescent food insecurity in rural Sindh, Pakistan: a cross-sectional survey. BMC Nutr. 6, 1-9.

Simons, D., Francis, M., Jones, D.T., 2005. Food value chain analysis, in: Consumer Driven Electronic Transformation. Springer, pp. 179-192.

Vaitla, B., Coates, J., Maxwell, D., 2015. Comparing household food consumption indicators to inform acute food insecurity phase classification. Washington, DC FHI 360.

Von Grebmer, K., Saltzman, A., Birol, E., Wiesman, D., Prasai, N., Yin, S., Yin, S., Yohannes, Y., Menon, P., Thompson, J., Sonntag, A., 2014. 2014 Global hunger index: the challenge of hidden hunger. IFPRI books.

Von Grebmer, K., Torero, M., Olofinbiyi, T., Fritschel, H., Wiesmann, D., Yohannes, Y., Olofinbiyi, T., Schofield, L. Von Oppeln, C., 2011. 2011 Global Hunger Index The challenge of hunger: Taming price spikes and excessive food price volatility. Intl Food Policy Res Inst.

Waha, K., Van Wijk, M.T., Fritz, S., See, L., Thornton, P.K., Wichern, J., Herrero, M., 2018. Agricultural diversification as an important strategy for achieving food security in Africa. Glob. Chang. Biol. 24, 3390-3400. 
Yousaf, H., Zafar, M.U., Zafar, M.O., Ahmad, S., Raza, Q.A., 2018. Regional distribution of food security and its determinants across regions of the Punjab, Pakistan. Pakistan J. Agric. Sci. 55, 711-717.

Publisher's note: Science Impact Publishers remain neutral with regard to jurisdictional claims in published maps and institutional affiliations.

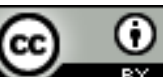

Open Access This article is licensed under a Creative Commons Attribution 4.0 International License, which permits use, sharing, adaptation, distribution and reproduction in any medium or format, as long as you give appropriate credit to the original author(s) and the source, provide a link to the Creative Commons license and indicate if changes were made. The images or other third-party material in this article are included in the article's Creative Commons license, unless indicated otherwise in a credit line to the material. If material is not included in the article's Creative Commons license and your intended use is not permitted by statutory regulation or exceeds the permitted use, you will need to obtain permission directly from the copyright holder. To view a copy of this license, visit https://creativecommons.org/licenses/by/4.0 /. 